\title{
HEREDITARY ANGIOEDEMA DUE TO C1-INHIBITOR DEFICIENCY IN PEDIATRIC PATIENTS IN CROATIA - FIRST NATIONAL STUDY, DIAGNOSTIC AND PROPHYLACTIC CHALLENGES
}

\author{
Ljerka Karadža-Lapić ${ }^{1}$, Marko Barešić ${ }^{2}$, Renata Vrsalović ${ }^{3}$, Irena Ivković-Jurekovićc, \\ Saša Sršen ${ }^{5}$, Ingrid Prkačin 6 , Matija Rijavec ${ }^{7}$ and Draško Cikojević ${ }^{8}$
}

${ }^{1}$ Department of Otorhinolaryngology, Šibenik General Hospital, Šibenik, Croatia;

${ }^{2}$ Division of Clinical Immunology and Rheumatology, Department of Internal Medicine, School of Medicine, University of Zagreb, Zagreb University Hospital Centre, Zagreb, Croatia; ${ }^{3}$ Department of Pediatrics, Sestre milosrdnice University Hospital Centre, Zagreb, Croatia; ${ }^{~}$ Zagreb Children's Hospital, Zagreb, Croatia;

Pediatric Department, Faculty of Medicine, Josip Juraj Strossmayer University of Osijek, Osijek, Croatia; ${ }^{5}$ Department of Pediatrics, Split University Hospital Centre, Split, Croatia; ${ }^{6}$ Department of Internal Medicine, School of Medicine, University of Zagreb, Merkur University Hospital, Zagreb, Croatia;

${ }^{7}$ Golnik University Clinic of Pulmonary and Allergic Diseases, Golnik, Slovenia;

${ }^{8}$ Department of Otorhinolaryngology, Split University Hospital Centre, Split, Croatia

SUMMARY - Hereditary angioedema (HAE) is a rare autosomal dominant disease with deficiency (type I) or dysfunction (type II) of C1 inhibitor, caused by mutations in the C1-INH gene, characterized by recurrent submucosal or subcutaneous edemas including skin swelling, abdominal pain and life-threatening episodes of upper airway obstruction. The aim of this study was to investigate healthcare experiences in children with HAE due to $\mathrm{C} 1$ inhibitor deficiency (C1-INH-HAE) in Croatia in order to estimate the number of affected children and to recommend management protocols for diagnosis, short-term prophylaxis and acute treatment. Patients were recruited during a 4-year period at five hospitals in Croatia. Complement testing was performed in patients with a positive family history. This pilot study revealed nine pediatric patients positive for C1-INH- HAE type I, aged 1-16 years, four of them asymptomatic. Before the age of one year, C1-INH levels may be lower than in adults; it is advisable to confirm C1-INH-HAE after the age of one year. Plasma-derived C1INH is recommended as acute and short-term prophylactic treatment. Recombinant C1-INH and icatibant are licensed for the acute treatment of pediatric patients. In Croatia, HAE is still underdiagnosed in pediatric population. Croatia

Key words: Hereditary angioedema types I and II - diagnosis; Complement C1 inbibitor protein; Child;

\section{Introduction}

Hereditary angioedema (HAE) due to $\mathrm{C} 1$ inhibitor deficiency (C1-INH-HAE) is a rare autosomal

\footnotetext{
Corresponding author: Ljerka Karadža-Lapić, MD, PhD, Šibenik General Hospital, Stjepana Radića 84, HR-22000 Šibenik, Croatia E-mail: ljerka.karadzalapic@gmail.com

Received August 21, 2017, accepted October 10, 2018
}

dominant disease with deficiency (type I C1-INH-HAE) or dysfunction (type II C1-INH-HAE) of C1 inhibitor (C1-INH) due to mutations in the SERPING1 gene $^{1-3}$. In some patients with a normal level of C1-INH, angioedema is related to mutation in coagulation factor XII gene (HAE-FXII), plasminogen (HAE-PLG) and angiopoetin-1 (HAE-ANGPT1), or the cause of angioedema remains 
unknown (U-HAE) ${ }^{2,4}$. All types of the disease share the same clinical presentation due to unregulated generation of bradykinin causing leakage of plasma from postcapillary venules ${ }^{5-7}$. Clinical events in the population with $\mathrm{C} 1-\mathrm{INH}-\mathrm{HAE}$ are characterized by recurrent submucosal or subcutaneous edemas including skin swelling, abdominal pain and life-threatening episodes of upper airway obstruction. Attacks may occur at any age after birth but early onset of symptoms may predict a more severe course of the disease, which worsens in puberty ${ }^{8}$. The most common attack triggers include mechanical trauma, stress and infections ${ }^{9,10}$. Also, dental-oral procedures, endoscopies or operations in general anesthesia with intubation can precipitate angioedema. If not treated, edema may persist for 1 to 5 days before resolving spontaneously ${ }^{11}$. The earliest and the most common swelling site in pediatric population is subcutaneous edema of the extremities. Upper airway edema is more severe in small children causing death by asphyxiation ${ }^{12,13}$. Abdominal pain, vomiting and diarrhea, frequent in general pediatric population, are present in $80 \%-90 \%$ of HAE patients $^{8}$. Edema can also affect genitalia, urinary bladder, muscles, joints, or can cause migraine or visual disturbances and headache ${ }^{8}$. The aim of this study was to investigate health care experiences in children with HAE in Croatia in order to estimate the number of affected children and to recommend management protocols for establishing HAE diagnosis, short- term prophylaxis before triggering procedures, and acute treatment of pediatric patients.

\section{Patients and Methods}

\section{Patients}

The patients were recruited during a 4-year period (2012-2016) at five hospitals in Zagreb, Šibenik and Split, Croatia. The diagnosis of C1-INH-HAE was established based on complement testing (complement $\mathrm{C} 4$ and $\mathrm{C} 1$ inhibitor antigenic levels) and characteristic clinical features such as upper airway and subcutaneous swelling or abdominal pain ${ }^{14}$. It was performed in nine patients from 18 families with confirmed C1-INH-HAE type I diagnosis. A questionnaire (Appendix), developed in line with the international consensus algorithm, was sent to each center, in order to explore patient experiences of the disease, including diagnosis and treatment ${ }^{2}$.
The study was approved by the participating hospital ethics committees and a parental written consent was granted.

\section{Complement testing}

Serum protein concentrations of $\mathrm{C} 1$ inhibitor (normal range: $0.20-0.35 \mathrm{~g} / \mathrm{L}$ ) and $\mathrm{C} 4$ (normal range: 0.16-0.31 g/L) were quantified using radial immunodiffusion (Siemens, Marburg, Germany). C1 inhibitor function was measured using an enzyme immunoassay (Quidel Corporation, California, USA) considering $\mathrm{C} 1$ inhibitor functional levels $\leq 40 \%$ of normal value as decreased levels. All measurements were performed in accordance with the manufacturer's instructions.

\section{Statistical analysis}

No formal statistical hypothesis was tested. Statistical analysis was essentially descriptive (percentages).

\section{Results}

Our pilot study identified nine children with HAE with positive family history, aged 0-16 years. All of them tested positive for C1-INH-HAE type I; four of them were asymptomatic (patient 1 , age 8 ; patient 3 age 15 ; patient 6 , age 6 ; and patient 9 , age 1 ) (Table 1 ). Detailed clinical data and complement measurements are outlined in Table 1 . There were six female $(F)$ and three male (M) patients. Age at onset of symptoms ranged from 1 to 15 years. The prime localization of the attacks was peripheral edema in $55 \%$ ( 5 patients = $3 \mathrm{~F}$, ages 6, 8 and 16; and $2 \mathrm{M}$, ages 4 and 10), followed by facial swelling in $33 \%$ ( 3 patients $=2 \mathrm{~F}$, ages 16 and 6 ; and $1 \mathrm{M}$, age 16$)$, and laryngeal (1 M, age 16$)$ and abdominal edema ( $1 \mathrm{~F}$, age 6$)$ in one patient $(12 \%)$ each. Abdominal pain as a symptom of HAE was the prime localization of attacks in patient 8 . In patient 2 with facial and neck edema, dental procedures precipitated facial and laryngeal attacks. Presentation of C1INH-HAE in the upper airways was detected in patient 4. This study identified three adolescents.

Plasma-derived C1-INH (pdC1-INH, human) was administered as acute treatment in the patient with laryngeal, facial and neck edema (20 IU per $\mathrm{kg}$ body weight by intravenous injection).

In this study, C1-INH-HAE was diagnosed before or immediately after symptom onset. 
Table 1. Patient clinical and laboratory data

\begin{tabular}{|c|c|c|c|c|c|c|c|c|c|c|c|}
\hline 莒 & 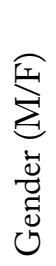 & $\underset{4}{4}$ & 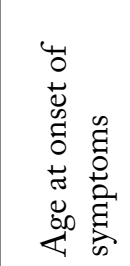 & 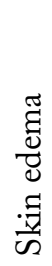 & 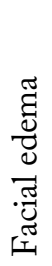 & 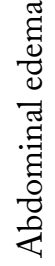 & 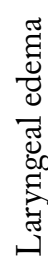 & 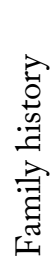 & 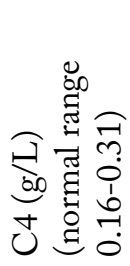 & 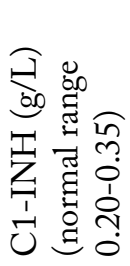 & 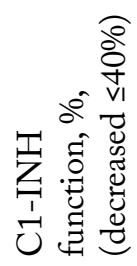 \\
\hline 1 & $\mathrm{~F}$ & 8 & Asympt & & & & & + & 0.05 & 0.05 & 36 \\
\hline 2 & $\mathrm{~F}$ & 16 & 15 & + & + & - & - & + & 0.05 & $<0.05$ & 30 \\
\hline 3 & $\mathrm{~F}$ & 15 & Asympt & & & & & + & 0.05 & 0.05 & 17 \\
\hline 4 & $\mathrm{M}$ & 16 & 6 & + & + & - & + & + & 0.06 & 0.05 & 20 \\
\hline 5 & $\mathrm{~F}$ & 8 & 3 & + & - & - & - & + & 0.15 & 0.09 & 33 \\
\hline 6 & $\mathrm{M}$ & 6 & Asympt & & & & & + & $<0.05$ & 0.06 & 24 \\
\hline 7 & M & 4 & 1 & + & - & - & - & + & 0.11 & 0.13 & 56 \\
\hline 8 & $\mathrm{~F}$ & 6 & 3 & + & + & + & - & + & 0.07 & 0.05 & 33 \\
\hline 9 & $\mathrm{~F}$ & 1 & Asympt & & & & & + & $<0.05$ & 0.15 & 48 \\
\hline
\end{tabular}

Asympt $=$ asymptomatic; $\mathrm{M}=$ male $; \mathrm{F}=$ female C1-INH = C1 inhibitor

\section{Discussion}

Using an estimated prevalence of 1:50 000 and national census statistics of 896605 children aged 19 years or less in Croatia, approximately 18 children would be expected to have this disease ${ }^{15}$. In this study, we detected nine children with C1-INH-HAE type I from 18 families with positive family history; one of them (patient 4) was the first family member with established proper $\mathrm{C} 1-\mathrm{INH}-\mathrm{HAE}$ diagnosis. $\mathrm{HAE}$ is a life-altering and chronic disease. This investigation emphasized the variety of clinical presentation of the disease and possible delay in reaching an accurate diagnosis due to that variety. C1-INH-HAE type I diagnosis is corroborated with low levels of serum protein concentrations of $\mathrm{C} 1-\mathrm{INH}$ and $\mathrm{C} 4$, and type II with low level of $\mathrm{C} 4$ and normal or above normal level of ineffective $\mathrm{C} 1-\mathrm{INH}$. The diagnosis can be further supported by genetic testing. All neonates/infants with an affected C1-INH-HAE family member should be screened for C1-INH deficiency; genetic testing is indicated under the age of one year ${ }^{14}$. Genetic testing is also indicated for HAE-FXII, HAE-PLG and HAEANGPT1 while U-HAE diagnosis can be established with positive family history and typical clinical presentation.

Complement testing is available in clinical centres throughout Croatia, while genetic testing can be per- formed in collaboration with the University Clinic of Pulmonary and Allergic Diseases Golnik, Slovenia, in agreement with the Croatian Health Insurance Fund ${ }^{10}$.

Abdominal pain commonly occurs in the general pediatric population. Differential diagnosis can be difficult as abdominal pain is common in pediatric $\mathrm{C} 1-$ INH-HAE population, as recorded in patient $8^{14}$. HAE is often underdiagnosed or misdiagnosed as a cause of abdominal pain. During abdominal edema attack, HAE patients are usually observed as cases of gastroenterocolitis or acute abdomen, or may undergo unnecessary surgical procedures ${ }^{16}$. Ultrasound findings of abdominal fluid and bowel swelling can help differentiate patients with $\mathrm{HAE}^{17}$. C1-INH-HAE diagnosis should be early established and also considered in patients experiencing recurrent angioedema with poor response to epinephrine, glucocorticoids and antihistamines, since they are ineffective in $\mathrm{C} 1-\mathrm{INH}$ $\mathrm{HAE}^{1,18-20}$. Some children may develop prodromal nonpruritic rash, erythema marginatum, but urticaria with itching at any age practically excludes HAE diagnosis $^{8,20}$.

\section{Puberty and oral hormonal contraceptives}

Puberty can aggravate the symptoms of HAE, particularly in females, triggered by menstruation and ovulation ${ }^{9}$. Estrogen-containing medications for acne 
or oral contraceptives can precipitate attacks, so they are not recommended in patients with $\mathrm{HAE}^{14}$.

\section{Medical procedures and $H A E$}

Physicians can trigger an HAE attack with their procedures. Dental procedures can precipitate facial and laryngeal attacks, as it was the case in patient 2 with facial and neck edema ${ }^{13}$. Presentation of $\mathrm{C} 1-$ INH-HAE in the upper airways, as in patient 4, may lead to asphyxiation, the time from symptom onset to asphyxiation varying from as little as 20 minutes to as long as 30 hours, making tracheotomy a lifesaving treatment ${ }^{13,21}$. Education of patients, parents and child care workers about laryngeal symptoms that may lead to asphyxiation, such as hoarseness, lump in the throat or shortness of breath, is crucial. Endoscopy procedures or operations in general anesthesia with intubation that are common in pediatric population, such as adenotonsillectomy or appendectomy, might lead to laryngeal edema or painful abdominal edema. PdC1INH is recommended as a short-term prophylactic treatment 1-2 hours before triggering procedures at a dose of $20 \mathrm{IU}$ per $\mathrm{kg}$ body weight by intravenous injection $^{14}$. If pdC1-INH is not available, attenuated oral androgen danazol $5 \mathrm{mg} / \mathrm{kg} /$ day or $10 \mathrm{~mL} / \mathrm{kg}$ solvent detergent plasma (SDP) can be administered ${ }^{14}$. Prophylaxis with danazol should start 5 days before and be continued for 2 days postprocedure. Treatment with pdC1-INH and recombinant C1-INH (rhC1-INH) to replace the functionally or quantitatively deficient C1-INH in patients with HAE has been shown to be effective for treating acute edematous attacks at any site in children. $\mathrm{PdC} 1-\mathrm{INH}$ is licensed for children at any age in a dose of $20 \mathrm{IU}$ per $\mathrm{kg}$ body weight and rhC1-INH (conestat alfa) or kallikrein inhibitor (ecallantide, only in the USA) for those older than 12 years ${ }^{14,22}$. Conestat alfa should be administrered at a dose of $50 \mathrm{IU}$ per $\mathrm{kg}$ body weight by intravenous injection $^{15}$. Icatibant administered in children and adolescents subcutaneously based on body weight has been recently approved for children above the age of 2 years ${ }^{15}$. Icatibant is approved for self-administration, allowing patients/families to take control of their disease. SDP is indicated in emergency situations when licensed therapy is not available (or fresh frozen plas$\mathrm{ma}(\mathrm{FFP})$ as a source of C1-INH). Individuals with HAE require lifelong therapy and evaluation of disease activity.

In conclusion, HAE is still underdiagnosed in pediatric population. This was the first survey of pediatric HAE in Croatia. According to these findings, we recommend comprehensive care, not only parental or medical, but also of all those included in the process of education in schools or kindergartens ${ }^{23}$. Also, identification card with individual treatment plan made by HAE specialist must be provided for each pediatric HAE patient. Dental-oral procedures, endoscopies or operations in general anesthesia can precipitate angioedema. Plasma-derived C1-INH is recommended as short-term prophylactic treatment before triggering procedures. Plasma-derived $\mathrm{C} 1-\mathrm{INH}$, recombinant C1-INH (for children above 12 years) and icatibant (for children above 2 years) are licensed for the acute treatment of pediatric patients. Raising awareness about rare diseases among parents and physicians is essential for early and accurate establishment of the diagnosis, effective management of acute attacks and prior to triggering procedures in order to avoid unnecessary investigations and to prevent adverse events.

\section{Acknowledgments}

The authors are grateful to Aleksandra Gošev, MD and Nenad Poljak, VD for great technical assistance. 


\author{
Appendix \\ Questionnaire for patients with hereditary angioedema
}

\title{
UPITNIK ZA PACIJENTE S HEREDITARNIM ANGIOEDEMOM
}

Datum datum rođenja

Ime i prezime

\section{MOLIM PODVUĆI:}

- dob pojave bolesti:

0-5 godina; 6-10 godina; 11-20 godina; >20 godina

- imao/la sam:

edem kože, bolni edem trbuha, edem grkljana, druge kliničke manifestacije

Znakovi bolesti posljednjih mjesec dana (navesti):

Uzimate li profilaksu (npr. Danazol tbl) DA NE

Ako DA navedite koju

označiti križićem:

\begin{tabular}{|l|l|l|l|l|l|l|}
\hline Znakovi bolesti & $\begin{array}{l}\text { Nema } \\
\text { smetnji }\end{array}$ & $\begin{array}{l}\text { Malo } \\
\text { uznemiru- } \\
\text { juće }\end{array}$ & $\begin{array}{l}\text { Neugodne } \\
\text { smetnje }\end{array}$ & $\begin{array}{l}\text { Jako } \\
\text { uznemiru- } \\
\text { juće }\end{array}$ & $\begin{array}{l}\text { Išao sam na } \\
\text { hitni prijam }\end{array}$ & $\begin{array}{l}\text { Koliko su česte u godini dana? } \\
\text { Prije preventivne th/ nakon } \\
\text { preventivne th }\end{array}$ \\
\hline $\begin{array}{l}\text { Otekline po koži } \\
\text { udova, trupa }\end{array}$ & & & & & & \\
\hline Otekline lica & & & & & & \\
\hline Otekline grla & & & & & & \\
\hline Bolovi u trbuhu & & & & & & \\
\hline
\end{tabular}

Znakovi bolesti prije započimanja preventivne terapije

\section{(molim navesti znakove bolesti i koliko puta godišnje su se javile):}

Što Vam izaziva napade bolesti? Molim podvući

infekcija napor trauma hormonska kontracepcija

Ostalo, što

Jeste li alergični na neki lijek? DA NE

Ako DA koji?

Bolujete li od neke druge bolesti? DA NE

ako Da koje

Uzimate li lijekove (navesti koje)? 
Imate li kod sebe lijek Berinert za samopomoć? DA NE

Imate li kod sebe lijek Firazyr za samopomoć? DA NE

Jeste li ikada primijenili lijek za samopomoć? DA NE

Jeste li ikada dobili neki od navedenih lijekova na hitnom prijmu? DA NE

Jeste li ikada imali ikakvu intervenciju (intubacija, traheotomija)? DA NE

Ako DA koju intervenciju?

Koju terapiju dobijete u akutnoj epizodi?

Vaši nalazi:

Koncentracija C4

Koncentracija C1 inhibitora

Imate li stečeno pomanjkanje $\mathrm{C} 1$ inhibitora? $\mathrm{DA} \mathrm{NE}$

Bolesni srodnici (npr. otac, sin...):

Klinički zdravi srodnici (nemaju simptome bolesti) s laboratorijski potvrđenim manjkom C1 inh (i sniženim C4)

Srodnici koje možemo pozvati na testiranje:

Obiteljsko stablo:

Suglasan sam s provođenjem genetske analize gena za hereditarni angioedem.

Ime i prezime datum

ništa jako

Koliko Vas bolest ometa u svakodnevnom životu? $1 \begin{array}{lllll}1 & 2 & 4 & 5\end{array}$

Koliko Vas bolest ometa na poslu? 12345

Jeste li kada doživjeli neugodnosti radi bolesti? $1 \begin{array}{lllllll}1 & 2 & 3 & 4 & 5\end{array}$

Smeta li Vašem partneru Vaša bolest? 122345

Utječe li Vaša bolest na kvalitetu Vašeg života? 1125445

Utječe li Vaša bolest na kvalitetu života Vaše obitelji? $1 \begin{array}{llllll}2 & 3 & 4 & 5\end{array}$

Jeste li član neke od udruga oboljelih od HAE? DA NE

Kako se informirate o svojoj bolesti?

Što biste predložili kao mjeru unaprjeđenja zdravstvene skrbi ili kvalitete života za oboljele od HAE? 


\section{References}

1. Zuraw BL, Christiansen SC. Pathophysiology of hereditary angioedema. Am J Rhinol Allergy. 2011;25(6):373-8, https:// doi.org/10.2500/ajra.2011.25.3661

2. Cicardi M, Aberer W, Banerji A, Bas M, Bernstein JA, Bork K, et al. Classification, diagnosis, and approach to treatment for angioedema: consensus report from the Hereditary Angioedema International Working Group. Allergy. 2014;69(5):602-16, https://doi.org/ 10.1111/all.12380

3. Kalmar L, Hegedus T, Farkas H, Nagy M, Tordai A. HAEdb: a novel interactive, locus-specific mutation database for the $\mathrm{C} 1$ inhibitor gene. Hum Mutat. 2005;25(1):1-5, https://doi. org/10.1002/humu.20112

4. Bjorkqvist J, de Maat S, Lewandrowski U, Di Gennaro A, Oschatz $\mathrm{C}$, Schonig K, et al. Defective glycosylation of coagulation factor XII underlies hereditary angioedema type III. J Clin Invest. 2015;125(8):3132-46, https://doi.org/10.1172/JCI77139

5. Zuraw BL, Christiansen SC. HAE Pathophysiology and underlying mechanisms. Clin Rev Allergy Immunol. 2016;51 (2):216-29, https://doi.org/10.1007/s12016-016-8561-8

6. Bjorkqvist J, Sala-Cunill A, Renne T. Hereditary angioedema: a bradykinin-mediated swelling disorder. Thromb Haemost. 2013;109(3):368-74, https://doi.org/ 10.1160/TH12-08-0549

7. Kaplan AP. Bradykinin and the pathogenesis of hereditary angioedema. World Allergy Organ J. 2011;4(4):73-5, https://doi. org/10.3389/fmed.2017.00206

8. Bork K, Meng G, Staubach P, Hardt J. Hereditary angioedema: new findings concerning symptoms, affected organs, and course. Am J Med. 2006;119(3):267-74, https://doi.org/ 10.1016/j.amjmed.2005.09.064

9. Farkas H.Pediatric hereditary angioedema due to $\mathrm{C} 1$-inhibitor deficiency. Allergy Asthma Clin Immunol. 2010;6(1):18, https://doi.org/10.1186/1710-1492-6-18

10. Rijavec M, Korosec P, Silar M, Zidarn M, Miljkovic J, Kosnik M. Hereditary angioedema nationwide study in Slovenia reveals four novel mutations in SERPING1 gene. PLoS One. 2013;8 (2):e56712, https://doi.org/10.1371/journal.pone.0056712

11. Agostoni A, Aygoren-Pursun E, Binkley KE, Blanch A, Bork $\mathrm{K}$, Bouillet L, et al. Hereditary and acquired angioedema: problems and progress: proceedings of the Third C1 Esterase Inhibitor Deficiency Workshop and beyond. J Allergy Clin Immunol. 2004;114(3 Suppl):S51-131, https://doi.org/10.1016/j. jaci.2004.06.047

12. Bork K, Barnstedt SE. Treatment of 193 episodes of laryngeal edema with $\mathrm{C} 1$ inhibitor concentrate in patients with hereditary angioedema. Arch Intern Med. 2001;161(5):714-8.
13. Bork K, Barnstedt SE. Laryngeal edema and death from asphyxiation after tooth extraction in four patients with hereditary angioedema. J Am Dent Assoc. 2003;134(8):1088-94.

14. Farkas H, Martinez-Saguer I, Bork K, Bowen T, Craig T, Frank $\mathrm{M}$, et al. International consensus on the diagnosis and management of pediatric patients with hereditary angioedema with $\mathrm{C} 1$ inhibitor deficiency. Allergy. 2016;72(2):300-13, https://doi. org/ 10.1111/all.13001

15. Markovic AS, Rozmanic V, Anic B, Aberle N, Racic G, Novak $\mathrm{S}$, et al. [Guidelines for the diagnosis and treatment of hereditary angioedema]. Lijec Vjesn. 2014; 136(5-6):117-29. Smjernice za dijagnostiku i lijecenje hereditarnog angioedema]. (in Croatian)

16. Lunn ML, Santos CB, Craig TJ. Is there a need for clinical guidelines in the United States for the diagnosis of hereditary angioedema and the screening of family members of affected patients? Ann Allergy Asthma Immunol. 2010;104(3):211-4, https://doi.org/10.1016/j.anai.2009.12.004

17. Sofia S, Casali A, Bolondi L. Sonographic findings in abdominal hereditary angioedema. J Clin Ultrasound. 1999;27(9): 537-40.

18. Craig T, Pursun EA, Bork K, Bowen T, Boysen H, Farkas H, et al. [WAO Guideline for the Management of Hereditary Angioedema]. Arerugi. 2015;64(9):1215-41, https://doi.org/10.15036/arerugi.64.1215 (in Japanese)

19. Bowen T, Cicardi M, Farkas H, Bork K, Longhurst HJ, Zuraw $\mathrm{B}$, et al. 2010 International consensus algorithm for the diagnosis, therapy and management of hereditary angioedema. Allergy Asthma Clin Immunol. 2010;6(1):24, https://doi.org/10.1186/1710-1492-6-24

20. Aberle N, Kljaic Bukvic B, Blekic M, Vuckovic M, Bardak D, Gudelj A, et al. Allergic diseases and atopy among schoolchildren in eastern Croatia. Acta Clin Croat. 2018;57(1):82-90, https://doi.org/10.20471/acc.2018.57.01.09

21. Nzeako UC, Frigas E, Tremaine WJ. Hereditary angioedema: a broad review for clinicians. Arch Intern Med. 2001;161(20): 2417-29.

22. Read N, Lim E, Tarzi MD, Hildick-Smith P, Burns S, Fidler KJ. Paediatric hereditary angioedema: a survey of UK service provision and patient experience. Clin Exp Immunol. 2014; 178(3):483-8.23, https://doi.org/10.1111/cei.12433

23. Vukojevic M, Zovko A, Talic I, Tanovic M, Resic B, Vrdoljak I, et al. Parental socioeconomic status as a predictor of physical and mental health outcomes in children - literature review. Acta Clin Croat. 2017;56(4):742-8, https://doi.org/10.20471/ acc.2017.56.04.23 


\title{
Sažetak
}

\section{HEREDITARNI ANGIOEDEM UZROKOVAN MANJKOM C1-INHIBITORA U PEDIJATRIJSKIH BOLESNIKA U HRVATSKOJ - PRVO NACIONALNO ISTRAŽIVANJE, DIJAGNOSTIČKI I PROFILAKTIČKI IZAZOVI}

\author{
Lj. Karadža-Lapić, M. Barešić, R. Vrsalović, I. Ivković-Jureković, S. Sršen, I. Prkačin, M. Rijavec i D. Cikojević
}

Hereditarni angioedem (HAE) je rijetka autosomno dominantna bolest nastala zbog mutacije gena SERPING1 za inhibitor plazmatskog proteina $\mathrm{C} 1$ (C1-INH). Uslijed manjka C1 inhibitora (tip I) ili njegove disfunkcionalnosti (tip II) dolazi do okidačem potaknute autoaktivacije C1-komponente komplementa i cijele kaskade koja dovodi do submukoznih ili subkutanih iznenadnih pojava oteklina kože, lica, kapaka, usana ili grla te abdominalnih bolova praćenih povraćanjem i dehidracijom. U najtežim slučajevima uslijed edema glotisa može doći do gušenja. Cilj ovoga istraživanja bila je procjena ukupnog broja djece s HAE zbog nedostatka C1 inhibitora (C1-INH-HAE) u Hrvatskoj kako bi se preporučili i provodili ujednačeni protokoli za dijagnozu, kratkotrajnu profilaksu i akutno liječenje. Pedijatrijski bolesnici su uključivani u istraživanje tijekom 4 godine u pet bolnica u Hrvatskoj. Svima s pozitivnom obiteljskom anamnezom na HAE analizirana je razina komplementa i C1 inhibitora. Probno istraživanje je otkrilo devet bolesnika pedijatrijske populacije u dobi od 1-16 godina koji su pozitivni za CI-INH-HAE tip I, od kojih su 4 bili asimptomatski. U slučaju akutnog napadaja HAE kao i za profilaktičnu primjenu preporuča se primjena pdC1-INH (humani inhibitor C1 esteraze). Također, rekombinantni C1-INH i ikatibant indicirani su za akutno liječenje pedijatrijskih bolesnika. U Hrvatskoj HAE je još uvijek nedovoljno dijagnosticiran u pedijatrijskoj populaciji.

Ključne riječi: Hereditarni angioedem, tipovi I i II-dijagnostika; Komplement C1 inhibitor protein, Dijete; Hrvatska 